\section{Applying Wollastonite to Soil to Adjust pH and Suppress Powdery Mildew on Pumpkin}

\author{
Yuan $\mathrm{Li}^{1}$, Arend-Jan Both ${ }^{2}$, Christian A. Wyenandt ${ }^{3}$, \\ Edward F. Durner ${ }^{1}$, and Joseph R. Heckman ${ }^{1}$
}

AdDitional INDEX WORDs. application rate, Cucurbita pepo, organic farming, plant pathology, silicon, soil fertility

Summary. Although not considered an essential nutrient, silicon (Si) can be beneficial to plants. Si accumulator species such as pumpkin (Cucurbita pepo var. pepo) can absorb Si from soil. Si uptake may reduce plant susceptibility to fungal diseases such as cucurbit powdery mildew (Podosphaera xanthii and Erysiphe cichoracearum). We previously reported that wollastonite, an Organic Materials Reviews Instituteapproved natural mineral, can increase soil Si level, increase soil $\mathrm{pH}$, provide pumpkin plants with $\mathrm{Si}$, and increase their resistance to powdery mildew. In this study, we examined the optimum application rate of wollastonite for pumpkins grown in pots and exposed to cucurbit powdery mildew. We confirmed that wollastonite has liming capabilities similar to regular limestone. Regardless of the application rates, wollastonite and limestone showed similar effects on soil chemistry and plant mineral composition. Pumpkin plants grown with the lower doses of wollastonite amendments (3.13 and 6.25 tons/acre) had the greatest tissue Si concentrations and demonstrated the greatest disease resistance. We conclude that wollastonite is a useful material for organic cucurbit (Cucurbitaceae) growers who want to increase soil $\mathrm{pH}$ and improve plant resistance to powdery mildew at the same time. Applying wollastonite at rates beyond the amount required to achieve a desirable soil $\mathrm{pH}$ for pumpkin production did not further increase Si uptake, nor did it further suppress powdery mildew development.

$\mathrm{P}$ umpkin is a globally important cash crop grown for the processing and fresh-market industries (Ingerson-Mahar et al., 2007). Nearly 2 billion pounds of pumpkin were harvested in the United States in 2017 (Gregory, 2018). One of

Received for publication 26 Apr. 2019. Accepted for publication 3 July 2019

Published online 24 September 2019.

${ }^{1}$ Department of Plant Biology, Rutgers University, 59 Dudley Road, New Brunswick, NJ, 08901

${ }^{2}$ Department of Environmental Sciences, Rutgers University, 14 College Farm Road, New Brunswick, NJ, 08901

${ }^{3}$ Department of Plant Biology, Rutgers University, Rutgers Agricultural Research and Extension Center, 121 Northville Road, Bridgeton, NJ 08302

We gratefully acknowledge U.S. Silica for financially supporting this research. We thank the School of Biological and Environmental Sciences for providing a fellowship and research support to Yuan Li for his Ph.D. studies at Rutgers University, and the New Jersey Agricultural Experiment Station.

The use of product and trade names in this publication is solely for the purpose of providing scientific information. No endorsement of a particular product is implied. Statements made in this publication do not constitute a specific endorsement of any products over others that may perform similarly.

J.R.H. is the corresponding author. E-mail: jheckman @njaes.rutgers.edu.

This is an open access article distributed under the CC BY-NC-ND license (https://creativecommons.org/ licenses/by-nc-nd/4.0/).

https://doi.org/10.21273/HORTTECH04391-19 the major problems associated with pumpkin is the risk of premature defoliation caused by foliar diseases such as powdery mildew. Podosphaera xanthii (formerly Sphaerotheca fuliginea) and Erysiphe cichoracearum are the two reported fungal species that can cause powdery mildew in cucurbit crops in the United States (Zitter et al., 1996). These pathogens can move long distances within the growing season, from southern to northern U.S. production areas (Zitter et al., 1996). Cucurbit powdery mildew infects leaves and vines at any growth stage, typically starting with the older leaves. Symptoms of powdery mildew include white colonies to large, coalesced white blotches on leaves causing chlorosis, and is eventually followed by loss of foliage. Powdery mildew can significantly reduce the yield of pumpkins both in terms of fruit size and number (Mossler and Nesheim, 2014; Zitter et al., 1996). Conventional and organic cucurbit growers take substantial efforts to control or mitigate losses to powdery mildew. Weekly applications of a fungicide can result in significant increases in cost, equipment, time, and labor. Most conventional fungicides currently used for cucurbit powdery mildew control have a high risk for resistance development (Wyenandt et al., 2018). The risk of losing fungicide efficacy for controlling diseases such as cucurbit powdery mildew requires continued efforts to help mitigate disease development through alternative means. Organic growers have fewer effective control options and face greater challenges when dealing with this pervasive disease. Organic growers can grow resistant or tolerant pumpkin cultivars, but additional disease control options are needed.

An approach that has gained attention recently includes improved soil fertility management and optimized plant nutrition (Datnoff et al., 2007). In particular, the application of $\mathrm{Si}$ as part of a fertilization strategy has been studied for typical Si accumulator species such as rice (Oryza sativa), wheat (Triticum aestivum), and cucurbits (Belanger et al., 2003; Elawad and Green, 1979; Heckman et al., 2003; Lepolu et al., 2016; Provance-Bowley et al., 2010). A review by Datnoff (2014) summarized the current understanding of the physiological significance of $\mathrm{Si}$ in plants. Si increases plant resistance to fungal diseases by either increasing the $\mathrm{Si}$ content in epidermal tissue, thus forming a thickened $\mathrm{Si}$-cellulose layer that is more resistant to fungal penetration, or by pathogenesis-mediated

\begin{tabular}{llll}
\hline $\begin{array}{l}\text { Units } \\
\text { To convert U.S. to SI, } \\
\text { multiply by }\end{array}$ & U.S. unit & SI unit & $\begin{array}{l}\text { To convert SI to U.S., } \\
\text { multiply by }\end{array}$ \\
\hline 0.3048 & $\mathrm{ft}$ & $\mathrm{m}$ & 3.2808 \\
0.0929 & $\mathrm{ft}^{2}$ & $\mathrm{~m}^{2}$ & 10.7639 \\
2.54 & $\mathrm{inch}(\mathrm{es})$ & $\mathrm{cm}$ & 0.3937 \\
0.4536 & $\mathrm{lb}$ & $\mathrm{kg}$ & 2.2046 \\
1 & $\mathrm{meq} / 100 \mathrm{~g}$ & $\mathrm{cmol} \cdot \mathrm{kg}^{-1}$ & 1 \\
28.3495 & $\mathrm{oz}$ & $\mathrm{g}$ & 0.0353 \\
1 & $\mathrm{ppm}$ & $\mathrm{mg} \cdot \mathrm{kg}^{-1}$ & 1 \\
2.2417 & $\mathrm{ton}(\mathrm{s}) / \mathrm{acre}$ & $\mathrm{Mg} \cdot \mathrm{ha}^{-1}$ & 0.4461 \\
$\left({ }^{\circ} \mathrm{F}-32\right) \div 1.8$ & ${ }^{\circ} \mathrm{F}$ & ${ }^{\circ} \mathrm{C}$ & $\left({ }^{\circ} \mathrm{C} \times 1.8\right)+32$
\end{tabular}


host defense responses (Zellner, 2017). In addition, a variety of crops, especially $\mathrm{Si}$ accumulators, showed increases in biomass, $\mathrm{Si}$ accumulation, and disease or pest resistance when treated with plant-available Si (Zellner et al., 2011, 2019). Although not officially regarded as an essential plant nutrient, $\mathrm{Si}$ is now widely considered a beneficial element for many plants (Datnoff, 2014; Datnoff et al., 2001). Several plant growth media companies have started to incorporate $\mathrm{Si}$ in their soil-less products.

Both conventional and organic growers are interested in the types and application rates of approved $\mathrm{Si}$ materials that can adequately address disease problems. Acquiring naturally derived and approved organic sources of $\mathrm{Si}$ for organic production has become a priority. In previous studies, members of our group identified and investigated the properties of several $\mathrm{Si}$ mineral sources, including earth-mined minerals such as wollastonite, MontanaGrow (MontanaGrow, Bonner, MT); glacial rock flour; and human-processed minerals such as wood ash and steel mill slag (Heckman et al., 2003; Lepolu et al., 2016). We used pumpkin as a model crop and investigated the beneficial effects of different amounts of Si amendments, including each amendment's ability to neutralize soil acidity, enhance $\mathrm{Si}$ uptake, improve powdery mildew control, and increase plant biomass. Wollastonite, a naturally occurring mineral form of calcium silicate $\left(\mathrm{Ca}_{2} \mathrm{SiO}_{4}\right)$, can provide all these tested beneficial effects to pumpkin plants. This product is naturally mined, and is listed by the Organic Materials Review Institute (OMRI; Eugene, OR) for use in organic production systems. We conducted experiments to understand further the effects of wollastonite on soil and plants under disease conditions, and to provide useful information to growers and the plant growth media industry. The objectives of our study were 1 ) to find the optimal soil amendment rate for wollastonite to achieve the best suppression of powdery mildew, 2) to determine wollastonite's ability to neutralize soil acidity and change soil chemistry compared with regular limestone, and 3 ) to investigate the biomass accumulation in pumpkin plants resulting from wollastonite soil applications.

Rates for liming material application are often determined based on initial soil $\mathrm{pH}$, target soil $\mathrm{pH}$ for the crop, and the liming requirement to reach that target. However, agronomists specializing in soil fertility not only need to provide sound advice on making optimum application rates of soil amendments, but also need to predict potential impacts on plant growth and crop mineral nutrition when target application rates are exceeded. Therefore, our greenhouse study was designed to include a wide range of wollastonite application rates, ranging from an unamended soil in need of liming, to a level that matched the lime requirement of the soil for growing pumpkin and most vegetable crops, as well as levels several orders of magnitude greater. Another reason for exploring greater application rates is that pumpkins are typically grown in widely spaced rows, permitting localized heavier application rates in the areas of seeding or transplanting that then are later dispersed by tillage. Application rates of wollastonite that might at first appear extremely high are more reasonable when one considers that future tillage can disperse the amendment across the field and extend the benefit to successive crops.

\section{Materials and methods}

Two similar experiments were conducted to evaluate the effectiveness of $\mathrm{Si}$ amendments. Expt. I started with seeding on 15 Apr. 2016. Expt. 2 started with seeding on 5 Dec. 2018. Expt. 1 was ended $35 \mathrm{~d}$ after seeding (DAS), whereas Expt. 2 was extended and ended 45 DAS.

A Readington loam (fine-loamy mixed, active, mesic Oxyaquic Fragiudalfs) soil was collected from the top $15 \mathrm{~cm}$ of soil at a local farm located in Hunterdon, NJ. This field had no recent history of limestone amendment or any chemical fertilizer or pesticide input, and had been managed based on organic farming techniques for at least the past 3 years. The collected soil was sieved through a homemade screen with square holes of $1 \mathrm{~cm}$ to remove pebbles and plant litter. The initial soil $\mathrm{pH}$ was $\mathbf{5 . 9 2}$ using the 1:1 soil volume-to-water ratio method. Soil tests for $\mathrm{Si}$ were performed using the method of Korndorfer (Datnoff et al., 2001). All extractions were analyzed by inductively coupled plasma atomic emission spectroscopy (ICP-AES). Individual 6.2-L plant containers (Poly-TainerCan \#2; Nurseries Supplies, Orange, CA) were filled with $10 \mathrm{~kg}$ of the soil.

We used a limestone with a calcium carbonate equivalent of 93 [containing 22\% calcium (Ca) and $1.2 \%$ magnesium $(\mathrm{Mg})$; Limestone Products Corp., Sparta, NJ] for the limestone-amended treatments. To achieve a soil $\mathrm{pH}$ of 6.5 , which is considered the optimum $\mathrm{pH}$ for growing pumpkins, the application rate for the limestone was calculated as 6.25 tons/acre based on initial $\mathrm{pH}$ and soil texture class.

We grew 'Connecticut Field' pumpkin plants (Stokes Seeds, Thorold, Ontario, Canada) in pots outdoors for 5 weeks to become naturally infected with cucurbit powdery mildew for use as a source of inoculum for Expt. 1. Expt. 1 was conducted in a double-layer, polyethylene-covered greenhouse located at the Rutgers University Vegetable Research Farm III in New Brunswick, NJ (lat. $40^{\circ} 27^{\prime} 45^{\prime \prime} \mathrm{N}$, long. $74^{\circ} 25^{\prime} 45^{\prime \prime} \mathrm{W}$; elevation, $21 \mathrm{~m}$ ), with a constant temperature set point of $70{ }^{\circ} \mathrm{F}$. Ten 'Connecticut Field' pumpkin seeds were sown in pots amended with different rates $(6.25,12.5,25$, or 50 tons/acre) of limestone or wollastonite [R.T. Vanderbilt Co., Norwalk, CT (OMRI listed)]. The control treatment consisted of pots filled with unamended soil. Before seeding, $10 \mathrm{~g}$ of blood meal (The Espoma Co., Millville, NJ) was mixed into the top $l$ inch of the soil in all pots. The experiment was designed as a randomized complete block with four replications. The full set of treatments was distributed randomly within a block, with one naturally infected plant per block.

Pots were thinned to one pumpkin plant per pot 1 week after germination. Powdery mildew lesions started to become visible on the cotyledons at 15 DAS. The total number of lesions on each plant was counted every other day. Powdery mildew was present on most leaves by 25 DAS and the percentage of total leaf area affected was estimated visually every 


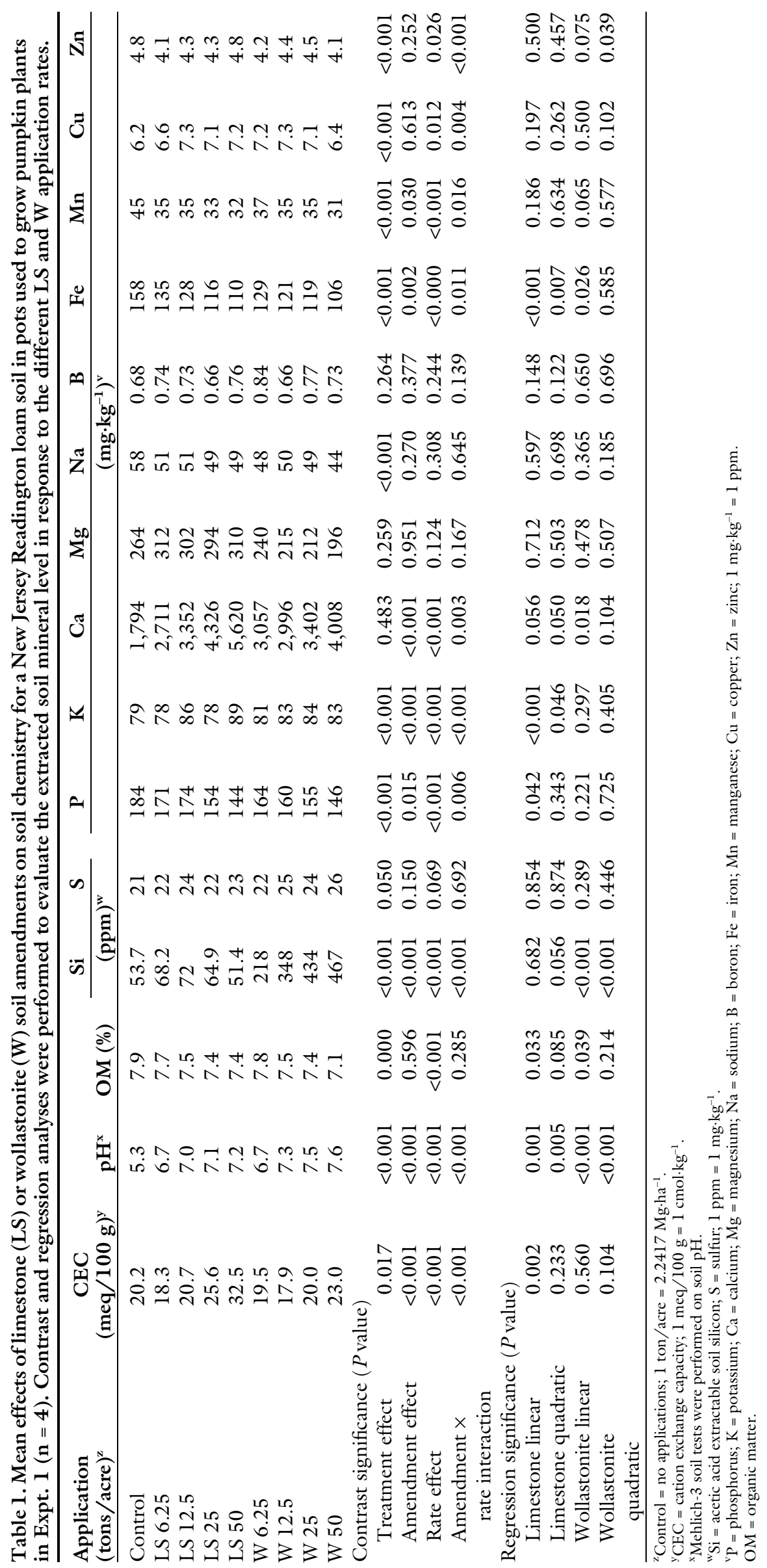




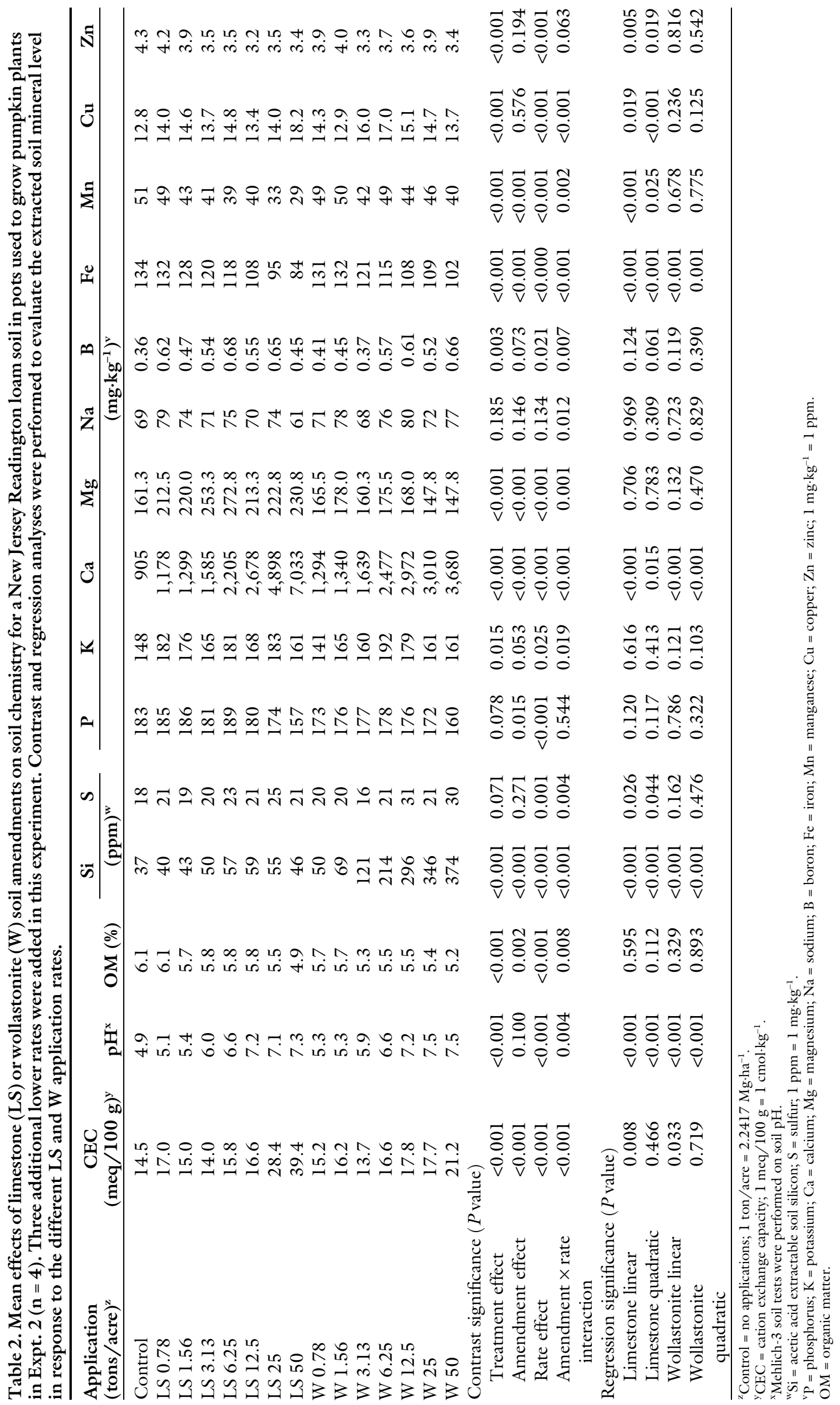


other day thereafter. The experiment was ended 35 DAS and all aboveground biomass from each pot was harvested. The biomass was dried at $68{ }^{\circ} \mathrm{C}$ for $5 \mathrm{~d}$ and weighed, and further analyzed for mineral composition using ICP-AES. To determine the Si content, the biomass samples were digested using 50\% sodium hydroxide, followed by colorimetric analysis at Brookside Laboratories (New Bremen, OH). Soil samples from all pots were collected by taking a soil core $(2-\mathrm{cm}$ diameter by $15-\mathrm{cm}$ depth) from each pot immediately after biomass harvest, and the samples from each pot were tested individually using the Mehlich-3 soil test. To determine the soil Si level, all soil samples were digested with acetic acid followed by colorimetric analysis at Brookside Laboratories.

For Expt. 2, we collected squash leaves that were heavily infected with powdery mildew from an outdoor location in Bridgeton, NJ (lat. $39^{\circ} 52^{\prime} 05^{\prime \prime} \mathrm{N}$, long. $75^{\circ} 20^{\prime} 50^{\prime \prime} \mathrm{W}$; elevation, $36 \mathrm{~m}$ ). The powdery mildew-infected leaves were placed among the pumpkin seedlings. The location, experimental design, and methods were identical to Expt. 1 , except we used three additional lower amendment rates $(0.78,1.56$, $3.13,6.25,12.5,25$, and 50 tons/ acre) for both limestone and wollastonite. Lesions of powdery mildew were first observed 15 DAS and the total number of lesions on each plant was counted every other day. We start to evaluate the percentage of total leaf area affected by 25 DAS. Expt. 2 was ended 45 DAS ( $10 \mathrm{~d}$ later than Expt. 1) to compensate for the slower plant growth in December. Biomass was collected, processed, and analyzed as described for Expt. 1.

The area under the disease progress curve (AUDPC) was calculated for each treatment in each experiment to measure disease development over time. The AUDPC values for each treatment were calculated using the trapezoidal rule (Sparks et al., 2008). All experimental data, including disease progress, soil chemical levels, and plant elemental analysis were analyzed in a stepwise fashion using SAS (version 9.4; SAS Institute, Cary, NC). A single $\mathrm{df}$ contrast comparing all treatments to the control was performed as a first step to determine whether there was a treatment effect. If a treatment effect was detected during this first step, a classic factorial analysis of amendments and rates was performed. The final step included linear and quadratic regression analyses of amendment rate.

\section{Results and discussion}

The different start times for the two experiments resulted in different natural light conditions. The average daily light integral (DLI) inside the greenhouse during Expt. 1 was $( \pm \mathrm{SD}) 23.78 \pm 11.30 \mathrm{~mol} \cdot \mathrm{m}^{-2}$. $\mathrm{d}^{-1}$, whereas the average DLI for Expt. 2 was $8.16 \pm 4.15 \mathrm{~mol} \cdot \mathrm{m}^{-2} \cdot \mathrm{d}^{-1}$. These differences had an impact on plant growth and development, as

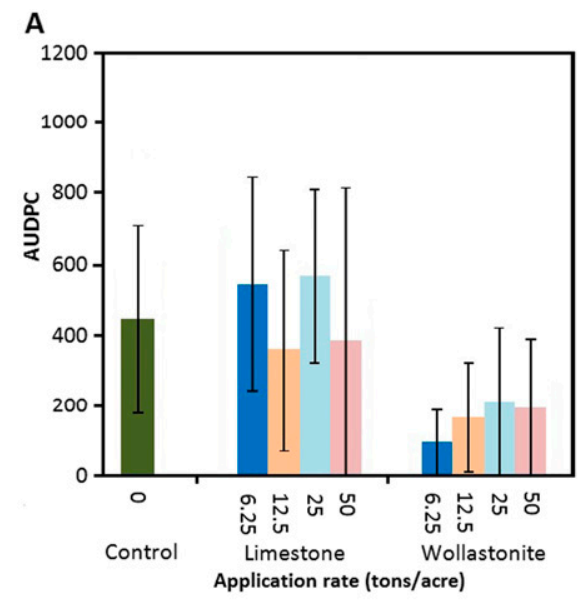

C

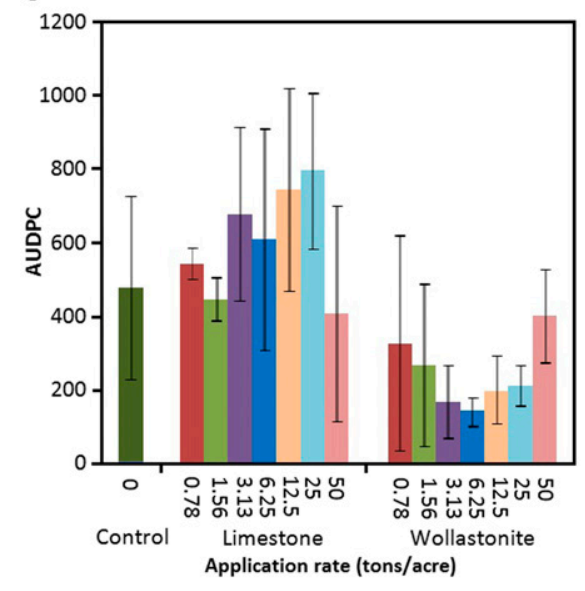

was observed from the differences in average final plant dry weight (average for control group, $23.22 \mathrm{~g} /$ plant for Expt. 1 and $2.82 \mathrm{~g} /$ plant for Expt. 2).

During both experiments, increasing the application rate of wollastonite increased the soil $\mathrm{Si}$ level significantly, whereas adding more limestone did not (Tables 1 and 2). Soil $\mathrm{pH}$ increased as the limestone and wollastonite application rates increased at similar rates, indicating that the acid-neutralizing abilities of limestone and wollastonite are similar. The extracted soil Ca level increased with both liming materials, but the wollastonite amendments decreased the extracted soil Mg level compared with limestone or the unamended soil.

B

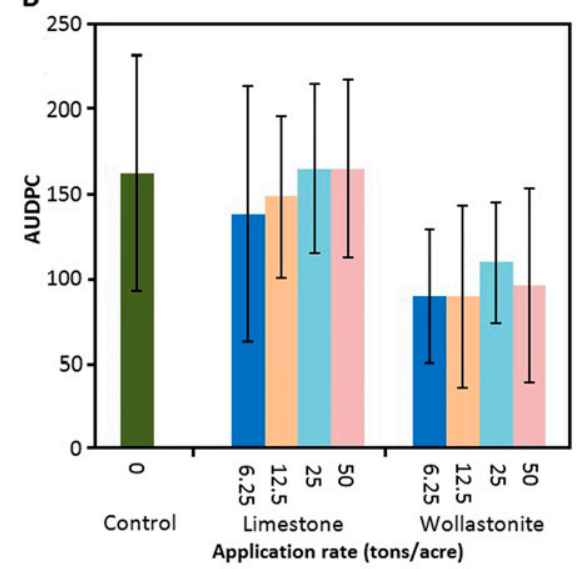

D

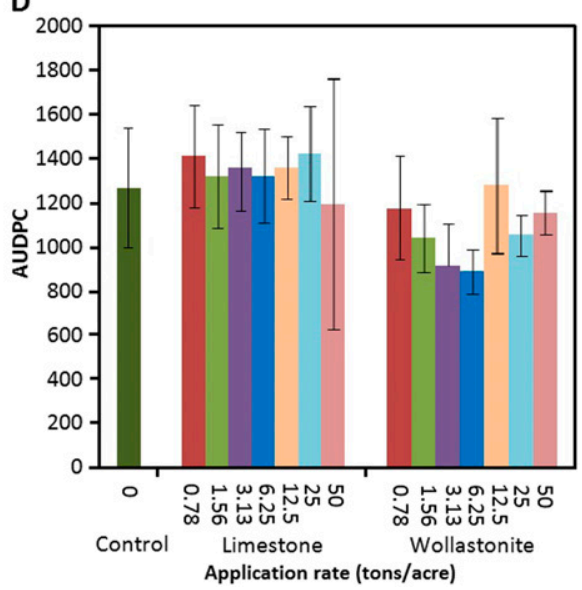

Fig. 1. Disease progression indicated by the areas under the disease progress curve (AUDPC) of powdery mildew on pumpkin plants $(n=4)$. Error bars indicate \pm SD. (A) Expt. 1 and (C) Expt. 2 disease progression (spot count) during earlier growth stage [between 15 and $23 \mathrm{~d}$ after seeding (DAS)]. (B) Expt. 1 and (D) Expt. 2 disease progression (area covered by coalescing colonies of powdery mildew) during the later growth stage (25-35 DAS for Expt. 1, 25-45 DAS for Expt. 2). 1 ton $/$ acre $=2.2417 \mathrm{Mg} \cdot \mathrm{ha}^{-1}$. 
Throughout the experiments, wollastonite-amended pumpkin plants exhibited lower disease levels, as shown by both powdery mildew colony counts and the percentages of leaf surface area coverage (Figs. 1 and 2). Based on AUDPC values, the disease level for all limestone treatments was not significantly different from the control group, but the wollastonite plants had fewer colonies and less surface area covered by powdery mildew (Fig. 1A-D). The time needed for colonies to coalesce and form large, infected areas was delayed for the wollastonite treatments. To reach 50 colonies on the 6.25 -ton/acre plants, wollastonitetreated plants took $6.8 \mathrm{~d}$ (Expt. 1) and $4.1 \mathrm{~d}$ (Expt. 2) longer than limestone plants. This indicates wollastonite delayed disease development, as shown in Fig. 3. However, higher levels of wollastonite application did not result in increased suppression of powdery mildew even as soil Si levels increased, as shown in Fig. 1. This result was consistent for both experiments.

When exposed to powdery mildew, wollastonite-amended pumpkin plants accumulated significantly more biomass by the end of both experiments (Fig. 4). During Expt.
1 , the greatest accumulated plant biomass was observed for the 12.5ton/acre wollastonite amendment, but the value was only marginally greater than the 25 -ton/acre treatment without being statistically significant $(P=0.930)$. During Expt. 2, the pathogen established itself much more quickly (data not shown), resulting in overall smaller plants and less uniform growth. The greatest biomass was observed at 3.13 tons/acre wollastonite, closely followed by the 6.25 - and 25 -ton/ acre rates $(P=0.745$ and 0.824 , respectively). During both experiments, wollastonite-treated plants had larger leaves, longer vines, and were bigger overall, as shown in Figs. 2 and 4.

The $\mathrm{Ca}$ concentration in the plant tissue increased similarly with increasing amendment rates of limestone or wollastonite (Tables 3 and $4)$. In plants, the uptake of one cation often results in less uptake of other cations. We observed this too because less $\mathrm{Mg}$ was taken up as a result of the limestone or wollastonite treatments compared with the unamended control treatment. The wollastonite amendments also decreased potassium uptake. Phosphorus $(\mathrm{P})$ uptake increased in the plants
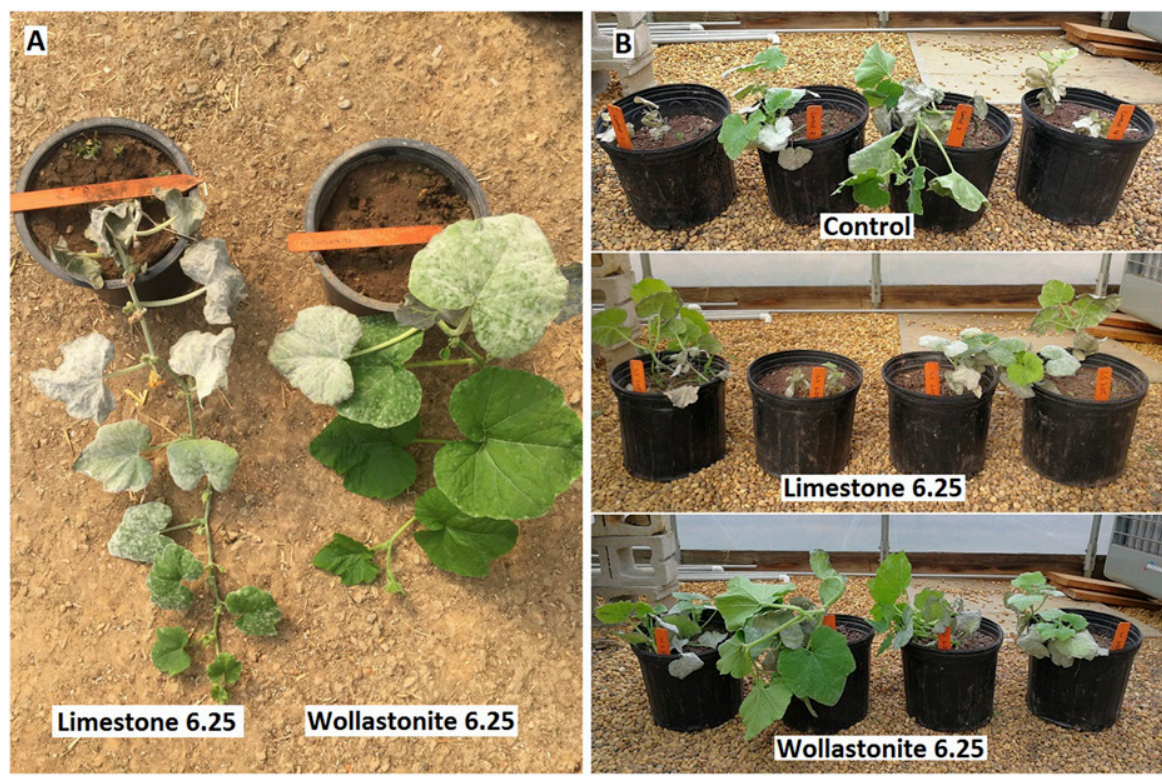

Fig. 2. Symptoms of powdery mildew development on pumpkin plants amended with (A) limestone 6.25 -ton/acre $\left(14.011 \mathrm{Mg} \cdot \mathrm{ha}^{-1}\right)$ and wollastonite 6.25 -ton/ acre treatment [end of Expt. 1, $35 \mathrm{~d}$ after seeding (DAS)], and (B) on plants from the control (no limestone or wollastonite applications), limestone 6.25-ton/acre and wollastonite 6.25-ton/acre treatments (end of Expt. 2, 45 DAS).

subject to wollastonite amendments, but not in plants subjected to limestone amendments, which agrees with previous research (Tubaña and Heckman, 2015) that found that amending soil with Si can enhance $\mathrm{P}$ availability. The uptake of micronutrients is sensitive to changes in soil $\mathrm{pH}$ (Bryson et al., 2014). As expected, boron, iron, manganese, copper, and zinc concentrations in plant tissue decreased with limestone or wollastonite amendments (Tables 3 and 4).

Limestone amendments had no significant impact on plant uptake of $\mathrm{Si}$ (Tables 3 and 4). However, the plant Si content increased as a result of the wollastonite amendments compared with the unamended control treatment. Most interestingly, the highest concentration of $\mathrm{Si}$ in the plants was observed at lower application rates of wollastonite. During Expt. 1, as the application rate of wollastonite increased from 6.25 to 50 tons/acre, a significant decrease in $\mathrm{Si}$ concentration in the plants was observed. During Expt. 2, the plant Si level was the highest at the 3.13-ton/acre treatment (Tables 3 and 4 ). Based on our results, there is no evidence that exceeding typical agronomic application rates of wollastonite (e.g., for the purpose of neutralizing soil acidity) will further increase Si uptake.

Similar to our previous work (Lepolu et al., 2016), the current study also found that wollastonite is both an effective liming material and an effective source of plant-available Si. Therefore, soil and crops may benefit from wollastonite amendments. This study demonstrated that wollastonite applications increased soil $\mathrm{pH}$, increased $\mathrm{Si}$ concentration in pumpkin plants, helped suppress powdery mildew, and enhanced plant P uptake. We observed an increase in biomass accumulation of pumpkin plants grown in Si-treated soil while under high powdery mildew pressure. Although this study focused on pumpkin, many other crops, especially $\mathrm{Si}$ accumulator plants, such as grain crops, may be able to use wollastonite to help increase plant growth and yields and to tolerate better foliar diseases such as powdery mildew (Tubaña and Heckman, 2015). Although not tested in our study, other researchers 
A

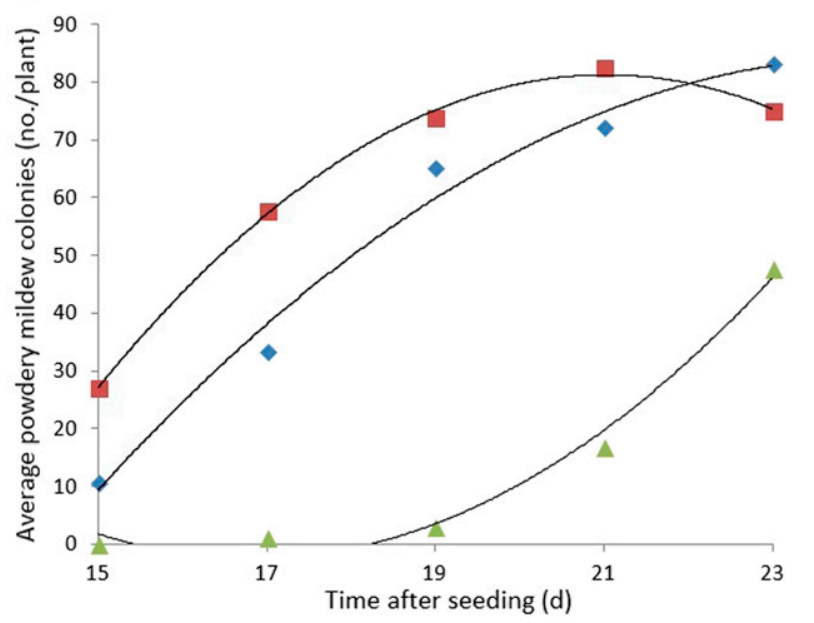

B

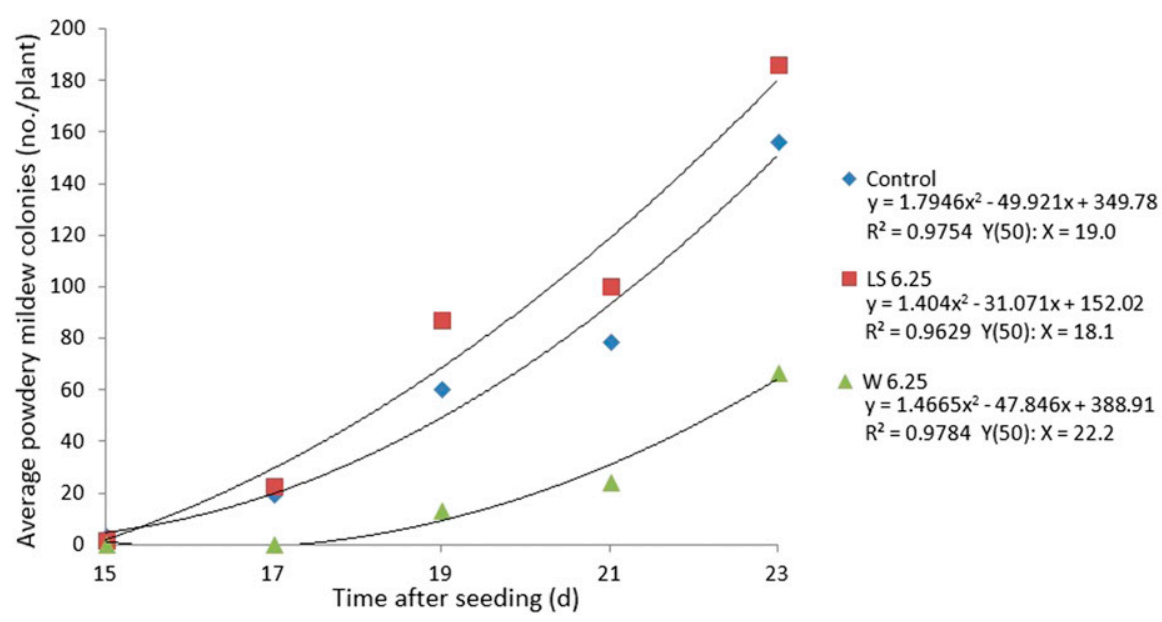

Fig. 3. Polynomial regression of disease progression during earlier (colony count) stage of powdery mildew on pumpkin plants [(A) Expt. 1, (B) Expt. 2], control (no application of limestone or wollastonite), 6.25 tons/acre $\left(14.011 \mathrm{Mg} \cdot \mathrm{ha}^{-1}\right.$ ) limestone (LS 6.25), and 6.25 tons/acre wollastonite (W 6.25). A calculation for the time needed to reach an average of 50 powdery mildew colonies on the plants was made based on the equations shown.
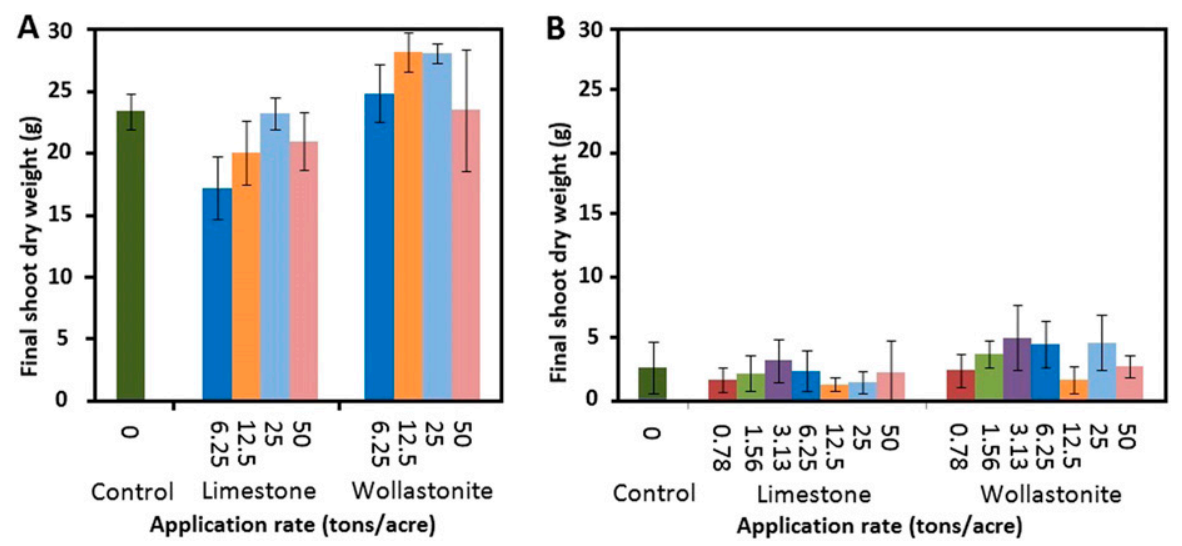

Fig. 4. Final shoot dry weight of pumpkin plants after being infected with powdery mildew for (A) Expt. 1 and (B) Expt. 2 (both, $n=4)$. Error bars indicate \pm SD. Expt. 1 was ended at $35 \mathrm{~d}$ after seeding (DAS); Expt. 2 was ended at 45 DAS. $\mathrm{l}$ ton $/$ acre $=2.2417 \mathrm{Mg} \cdot \mathrm{ha}^{-1}, \mathrm{lg}=\mathbf{0 . 0 3 5 3} \mathrm{oz}$. have shown that $\mathrm{Si}$-amended crops had an increase in tissue firmness and were less susceptible to insect attacks (Datnoff, 2014; Datnoff et al., 2001).

Our results showed that wollastonite applications have similar liming effects as regular limestone, and marginally change soil chemistry compared with applying regular limestone. Although it is more expensive, wollastonite can be used as a liming agent with the same effectiveness as common agricultural limestone. As with limestone applications, there was no additional benefit to powdery mildew suppression when the wollastonite application rates were increased beyond what is needed to reach the target soil $\mathrm{pH}$. Greater application rates of wollastonite did not increase, but rather decreased the Si concentration in plants, as well as reduced the plant's ability to suppress powdery mildew. We do not know the reason why our plants exhibited lower $\mathrm{Si}$ uptake rates when more wollastonite was added to the soil beyond the application rate needed to reach the target soil $\mathrm{pH}$. We do not think soil $\mathrm{pH}$ contributes to this phenomenon, because both wollastonite and limestone amendments increased the soil $\mathrm{pH}$ equally well. Si needs to be rootabsorbed to change plant response to pathogen infection at both the physiological and molecular level. Our results showed that disease suppression correlated positively with the $\mathrm{Si}$ concentration in plants, but not with the Si concentration in the soil. As a result, the observed increase in biomass did not have a linear relationship with an increased wollastonite level in the soil. Although the impact of powdery mildew was the lowest at 3.13 and 6.25 ton/acre wollastonite, shoot biomass was increased for not only the lower, but also the higher wollastonite applications as well. Our findings suggest that going beyond the normal agronomic rate needed to reach the target soil $\mathrm{pH}$ for pumpkin is not necessarily harmful to biomass yield. Therefore, pumpkin growers with fields that already have an optimum soil $\mathrm{pH}$ could still apply a moderate rate of wollastonite to obtain the benefits of enhancing plant Si uptake for powdery mildew suppression. 


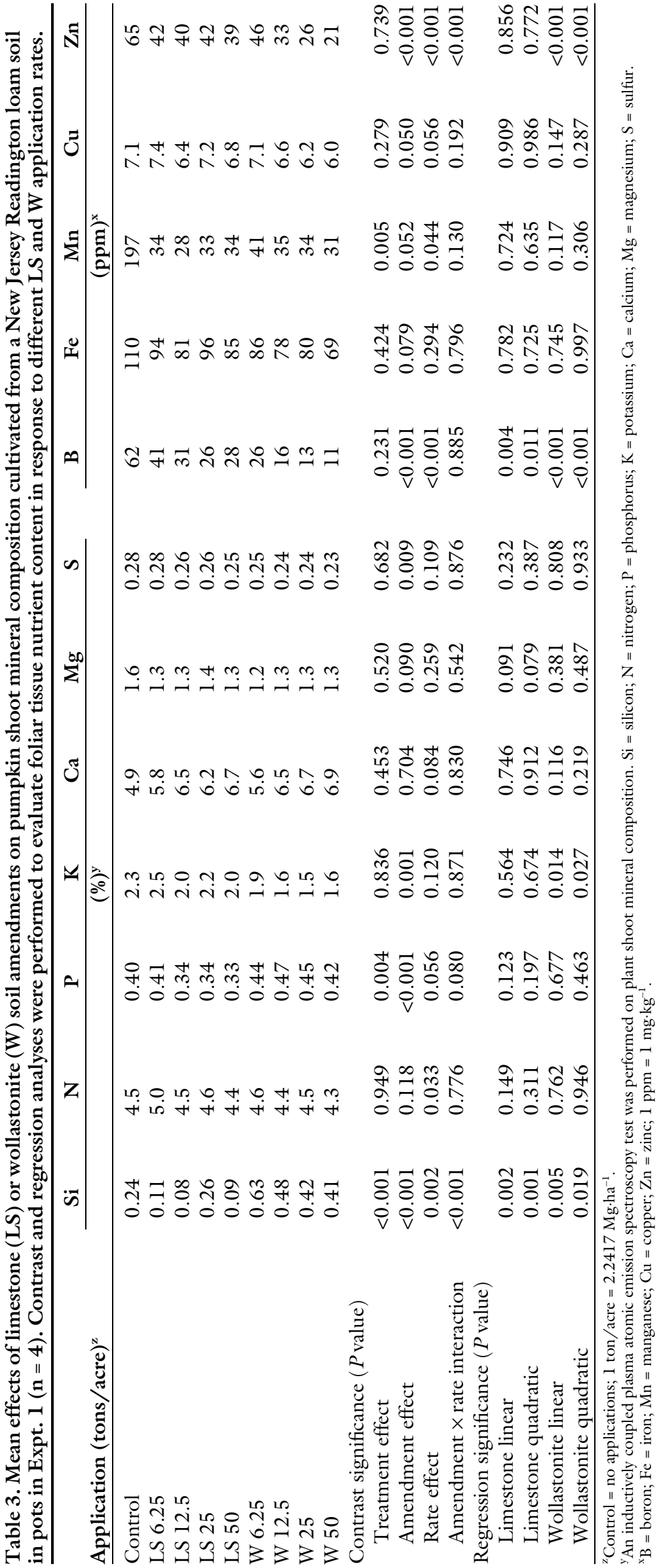

To reveal the reason for why the lower wollastonite amendment rates resulted in greater $\mathrm{Si}$ concentrations in pumpkin, future research is needed to study plant growth and development under nondisease conditions, possibly using different soil types. For a pot experiment conducted in a greenhouse, soil and air temperature are more similar than field cultivation, where the soil temperature is usually considerably lower than the air temperature. Soil moisture distribution can also be less controlled. Therefore, the solubility, availability, and uptake of $S$ i by plants grown in the field could be different from plants grown in pots in a greenhouse. Although wollastonite appears effective at reducing powdery mildew development in pumpkin, there could be other benefits from using wollastonite as liming material instead of limestone even in the absence of disease pressure. Moreover, our study was ended before the fruiting stage, and careful evaluation of plant and fruit characteristics, as well as yields and tissue elemental analysis throughout the entire growth period of healthy pumpkin crops will be of great interest to growers. Any residual effects of wollastonite amendments to soils compared with limestone amendments over multiple cropping cycles with $\mathrm{Si}$ accumulators or nonaccumulators will also be of interest to growers.

Naturally mined Si sources such as wollastonite can be used in organic farming. We found that wollastonite can suppress powdery mildew development and neutralize soil acidity at the same time, but the optimum application rate must be carefully considered, because we found that lower application rates yielded the best results. Organic growers are encouraged to inquire with certifiers and researchers before deciding on amendment rates for certified farmland. Although some OMRI-listed products are currently being used by organic growers, our previous research (Lepolu et al., 2016) has shown that several of these materials are effective as a source of $\mathrm{Si}$, but are less effective as liming agents. In the case of wollastonite, if applied to acidic soils, the combined benefits of a liming agent with potential fungal disease suppression may be of great interest to organic growers. 


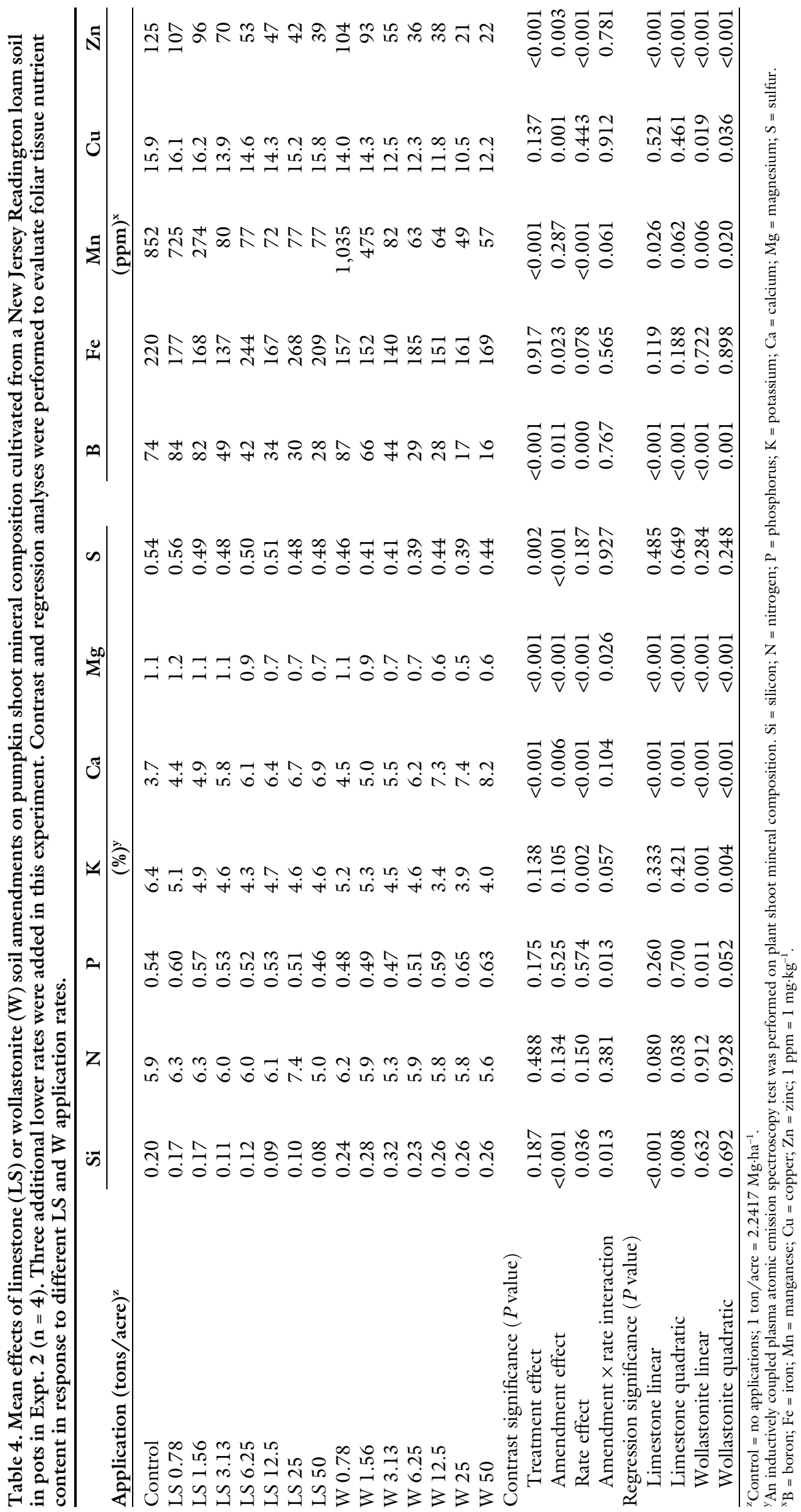




\section{Literature cited}

Belanger, R.R., N. Benhamou, and J.G. Menzies. 2003. Cytological evidence of an active role of silicon in wheat resistance to powdery mildew (Blumeria graminis $\mathrm{f}$. sp. tritici). Phytopathology 93:402-412.

Bryson, G.M., H.A. Mills, D.N. Sasseville, J.B. Jones, Jr., and A.V. Barker. 2014. Plant analysis handbook III. Micro-Macro, Athens, GA.

Datnoff, L.E. 2014. Silicon products: Helping plants overcoming biotic and abiotic stresses. NewAG Intl. 2016: 32-37.

Datnoff, L.E., W.H. Elmer, and D.M. Huber. 2007. Mineral nutrition and plant disease. APS Press, St. Paul, MN.

Datnoff, L.E., G.H. Snyder, and G.H. Korndörfer. 2001. Silicon in agriculture. lst ed. Elsevier, Amsterdam, The Netherlands.

Elawad, S.H. and V.E. Green, Jr. 1979. Silicon and the rice plant environment: A review of recent research. Riso 28:235253.

Gregory, A. 2018. Pumpkins: Background and statistics. 24 Oct. 2018. <https:// www.ers.usda.gov/newsroom/trendingtopics/pumpkins-background-statistics/>.
Heckman, J.R., S. Johnston, and W. Cowgill. 2003. Pumpkin yield and disease response to amending soil with silicon. HortScience 38:552-554.

Ingerson-Mahar, J., J. Rabin, and C.A. Wyenandt. 2007. Pumpkin crop profile for New Jersey. 20 May 2019. <http:// njinpas.rutgers.edu/CropProfiles/ pumpkinCP.pdf $>$.

Lepolu, T.J., J.R. Heckman, J.E. Simon, and C.A. Wyenandt. 2016. Silicon soil amendments for suppressing powdery mildew on pumpkin. Sustainability 8:293.

Mossler, M.A. and O.N. Nesheim. 2014. UF IFAS extension crop/pest management profile: squash. Univ. of Florida IFAS Extension.

Provance-Bowley, M., J.R. Heckman, and E.F. Durner. 2010. Calcium silicate suppresses powdery mildew and increases yield of field grown wheat. Soil Sci. Soc. Amer. J. 74:1652-1661.

Sparks, A.H., P.D. Esker, M. Bates, W.W. Dall' Acqua, Z. Guo, V. Segovia, S.D. Silwal, S. Tolos, and K.A. Garrett. 2008. Ecology and epidemiology in R: Disease progress over time. The Plant Health Instructor, APS, St. Paul, MN.

Tubaña, B.S. and J.R. Heckman. 2015. Silicon in soils and plants, p. 7-51. In:
F.A. Rodrigues and L.E. Datnoff (eds.). Silicon and plant diseases. Springer-Verlag, Berlin, Germany.

Wyenandt, C.A., M.T. McGrath, K.L. Everts, S.L. Rideout, B.K. Gugino, and N. Kleczewski. 2018. Resistance management guidelines for cucurbit downy and powdery mildew control in the midAtlantic and northeast regions of the United States in 2018. Plant Health Prog. 18:34-36.

Zellner, W. 2017. Understanding differences in silicon uptake between high and low foliar accumulators: Concentration may not predict protection. Soil Sci. Soc. Amer. Annu. Mtg., Tampa, FL (abstr.).

Zellner, W., J. Frantz, and S. Leisner. 2011. Silicon delays tobacco ringspot virus systemic symptoms in Nicotiana tabacum. J. Plant Physiol. 168:18661869.

Zellner, W., L. Lutz, S. Khandekar, and S. Leisner. 2019. Identification of NtNIP2;1: An Lsil silicon transporter in N. tabacum. J. Plant Nutr. 42:10281035 .

Zitter, T.A., D.L. Hopkins, and C.E. Thomas. 1996. Compendium of cucurbit disease. APS Press, St. Paul, MN. 